\title{
Glutamate Receptor Exocytosis and Spine Enlargement during Chemically Induced Long-Term Potentiation
}

\author{
Charles D. Kopec, ${ }^{\star}$ Bo Li, ${ }^{\star}$ Wei Wei, Jannic Boehm, and Roberto Malinow \\ Cold Spring Harbor Laboratory, Cold Spring Harbor, New York 11724
}

The changes in synaptic morphology and receptor content that underlie neural plasticity are poorly understood. Here, we use a pHsensitive green fluorescent protein to tag recombinant glutamate receptors and monitor their dynamics onto dendritic spine surfaces. We show that chemically induced long-term potentiation (chemLTP) drives robust exocytosis of AMPA receptors. In contrast, the same stimulus produces a small reduction of NMDA receptors from the spine surface. chemLTP produces similar modification of small and large spines. Interestingly, during chemLTP induction, spines increase in volume before accumulation of AMPA receptors on their surface, indicating that distinct mechanisms underlie changes in morphology and receptor content.

Key words: AMPA receptor; NMDA receptor; long-term potentiation; exocytosis; trafficking; two-photon microscopy

\section{Introduction}

Excitatory synapses are generally placed on dendritic spines (Harris and Kater, 1994) and contain AMPA and NMDA-type glutamate receptors (GluRs) (Takumi et al., 1999; Racca et al., 2000). Glutamate receptors are tetrameric ligand-gated ion channels composed of different subunits (Mayer and Armstrong, 2004). In adult hippocampus, pyramidal neuron synapses contain AMPA receptors (AMPARs) composed of GluR1 and GluR2 or GluR2 and GluR3 (Wenthold et al., 1996). Synaptic NMDA receptors (NMDARs) contain NR1 and NR2A or NR2B subunits (Monyer et al., 1994; Sheng et al., 1994). The rapid movement of transmembrane proteins on and off the surface of neuronal and non-neuronal cells by exocytosis or endocytosis, respectively, has been appreciated for a number of years (Burgess and Kelly, 1987). It is only recently that such rapid processes have been examined for the trafficking of AMPARs and NMDARs (Malinow and Malenka, 2002; Sheng and Kim, 2002; Song and Huganir, 2002; Bredt and Nicoll, 2003; Collingridge et al., 2004).

Excitatory synapses display activity-dependent changes in their strength. These phenomena have attracted much attention, because such modifications are likely to underlie learning and memory. One form of cellular plasticity, long-term potentiation (LTP) (Bliss and Lomo, 1973), a rapid enhancement of transmission after a brief period of high synaptic activity, has provided insight into plastic events that are driven by experience (Lisman,

\footnotetext{
Received Sept. 15, 2005; revised Jan. 3, 2006; accepted Jan. 5, 2006.

This work was supported by the National Institutes of Health (R.M., C.D.K.), the Canadian Institute of Health Research (B.L.), the Lindsay-Goldberg Fellowship (C.D.K.), the Fidelity Foundation (R.M.), the Leslie C. Quick Fellowship (W.W.), and the Deutsche Forschungsgemeinschaft and the Alzheimer's Association (J.B.). We thank Nancy Dawkins for preparation of hippocampal slice cultures; Barry Burbach, Peter O'Brien, and Dr. Svoboda for assistance on the microscope; Drs. Tsien and Miesenbock for supplying reagents; and members of the Malinow laboratory for helpful discussions in preparing this manuscript.

${ }^{*}$ C.D.K. and B.L. contributed equally to this work

Correspondence should be addressed to Roberto Malinow, Cold Spring Harbor Laboratory, 1 Bungtown Road, Cold Spring Harbor, NY 11724.E-mail: malinow@cshl.edu.

DOI:10.1523/JNEUROSCI.3918-05.2006

Copyright $\odot 2006$ Society for Neuroscience $\quad$ 0270-6474/06/262000-10\$15.00/0
}

2003; Morris et al., 2003; Tonegawa et al., 2003). Although much is known, the cellular and molecular mechanisms responsible for LTP are not fully understood (Malinow and Malenka, 2002; Sheng and Kim, 2002; Song and Huganir, 2002; Bredt and Nicoll, 2003; Johnston et al., 2003; Collingridge et al., 2004).

In general, during LTP induction, NMDARs are activated, allowing calcium entry that triggers signaling pathways (Sheng and Kim, 2002). These events lead to synaptic incorporation of AMPARs (Malinow and Malenka, 2002), which produces enhanced transmission. NMDARs can also be rapidly regulated after being activated, which may affect subsequent plasticity (Carroll and Zukin, 2002; Collingridge et al., 2004; Quinlan et al., 2004). In addition to effects on glutamate receptor dynamics, LTP can produce structural changes leading to increased number and size of dendritic spines (Engert and Bonhoeffer, 1999; Maletic-Savatic et al., 1999; Matsuzaki et al., 2004). Despite these advances, the spatiotemporal dynamic relationships among AMPARs, NMDARs, and spines during plasticity are not well understood. For instance, although exocytosis appears required for LTP (Lledo et al., 1998; Park et al., 2004), does exocytosis of AMPA receptors occur during LTP? Are structural changes in spines temporally linked to the surface appearance of AMPA receptors? Is trafficking of NMDA receptors linked to LTP? A number of similar questions that address key mechanisms during LTP have remained unresolved.

Here, we approach these issues by making use of recent advances in imaging technology. We use dual channel time-lapse two-photon laser-scanning microscopy (TPLSM) to monitor trafficking of glutamate receptors and neuronal morphology simultaneously. Until now, real-time measurements of receptor exocytosis onto the surface of neurons have not been possible. Recently, green fluorescent protein (GFP) variants have been generated that display strong $\mathrm{pH}$-dependent fluorescence (ecliptic pHluorins) (Miesenbock and Rothman, 1998). These molecules have been used to study vesicle trafficking in presynaptic terminals (Sankaranarayanan et al., 2000; Gandhi, 2003) and 
postsynaptic receptor endocytosis (Ashby et al., 2004). The large $\mathrm{pH}$ shift experienced by proteins within the synaptic vesicles during exocytosis is translated into a large increase in absolute fluorescence (Sankaranarayanan et al., 2000). Here, we used a similar strategy to monitor exocytosis and surface dynamics of AMPA and NMDA receptor subtypes in organotypic hippocampal slices after a chemically induced form of LTP (chemLTP) (Otmakhov et al., 2004). With coexpression of a cytoplasmic marker, we captured dynamics of dendritic spines and exocytosis of receptors simultaneously.

We show that chemLTP rapidly enhances spine size with subsequent surface incorporation of GluR1 AMPA receptors. During chemLTP, GluR1 receptors increase on spine surfaces with no significant net change on the nearby dendrite. GluR2 receptors increase moderately and transiently on the spine surface. NMDA receptors show either a small decrease (NR2B) or no change (NR2A). The increase in spine volume produced by chemLTP is similar in small and large spines and independent of initial NR2A or NR2B content. These results identify multiple spatiotemporal processes that orchestrate the generation of LTP.

\section{Materials and Methods}

Plasmid construction. The super-ecliptic pHluorin (SEP) coding sequence (G. Miesenbock, personal communication) was inserted three amino acids downstream of the predicted signal peptide cleavage site of the corresponding AMPAR subunit, after amino acid 26 in NR2A, after amino acid 31 in NR2B. The resultant product was inserted into the mammalian expression vector $\mathrm{pCI}$ (Promega, Madison, WI) to generate pCI-SEP-GluR1, pCI-SEP-GluR2, pCI-SEP-NR2A, and pCI-SEP-NR2B. To create NR2 mutants that permit transmission at $-60 \mathrm{mV}$, the $\mathrm{N}+1$ site asparagine (N596) of NR2A or equivalent site asparagine of NR2B was mutated to glutamine (Q) by standard PCR method (Wollmuth et al., 1998). The red fluorescent protein (tDimer dsRed), a fast maturing obligate dimer version of dsRed (provided by R. Tsien, University of California San Diego, La Jolla, CA), was inserted into pCI.

Slice culture and transfection. Organotypic hippocampal slices were prepared from postnatal day 6 or 7 animals (Stoppini et al., 1991), transfected after $17-20 \mathrm{~d}$ in culture, and imaged 2-3 d after transfection. Coexpression of two constructs was achieved using biolistics transfection (Arnold et al., 1994).

Two-photon laser-scanning microscopy and chemLTP induction. Experiments were performed at $30^{\circ} \mathrm{C}$ in physiological artificial CSF (ACSF) (in mм: $119 \mathrm{NaCl}, 26 \mathrm{NaHCO}_{3}, 1 \mathrm{NaH}_{2} \mathrm{PO}_{4}, 11$ D-glucose, $2.5 \mathrm{KCl}, 4 \mathrm{CaCl}_{2}$, $4 \mathrm{MgCl}_{2}$, and $1.25 \mathrm{NaHPO}_{4}$ ) gassed with $5 \% \mathrm{CO}_{2}$ and $95 \% \mathrm{O}_{2}$. The chemLTP induction solution consisted of the above ACSF lacking $\mathrm{MgCl}_{2}$ and containing $100 \mathrm{~nm}$ Rolipram, $50 \mu \mathrm{M}$ forskolin, and $100 \mu \mathrm{M}$ picrotoxin (all dissolved in DMSO at $1000 \times$ ). When indicated, both basal and induction ACSF were supplemented with $100 \mu \mathrm{M}$ DL-APV. Before TPLSM imaging, transfected CA1 pyramidal neurons were identified by epifluorescence illumination. A standard region encompassing the initial bifurcation of the CA1 neuron was chosen for data acquisition. Highresolution three-dimensional image stacks were collected on a custombuilt instrument based on a Fluoview laser-scanning microscope (Olympus America, Melville, NY). The light source was a mode-locked Ti: sapphire laser (Mira 900F; Mira, Santa Clara, CA) running at $910 \mathrm{~nm}$. We used a LUMPlanFl/IR $40 \times 0.80$ numerical aperture objective. Each optical section was resampled three times and was captured every $0.5 \mu \mathrm{m}$ (supplemental Fig. 1, available at www.jneurosci.org as supplemental material). Two full stacks were captured (at -30 and $-10 \mathrm{~min}$ ) before chemLTP induction. One stack was captured during the 16 min induction at $+5 \mathrm{~min}$ and two after induction at +40 and $+70 \mathrm{~min}$. During the chemLTP induction, $10 \mathrm{ml}$ of the induction solution was allowed to flow through before recycling to prevent mixing of the solutions. After the 16 min induction, $10 \mathrm{ml}$ of the basal solution was allowed to flow through before recycling.

Image display. All images displayed in the manuscript are data from two to three consecutive stacks displayed using a maximum value pro- jection. At any given $x-y$ coordinate, the maximum pixel value in that $\mathrm{Z}$-column is displayed in the two-dimensional image. Ratio images are displayed for two-channel data (green/red; i.e., receptor/volume) and mapped in pseudocolor with red representing a high ratio and blue a low ratio. Image analysis was conducted on raw data using full Z-stacks as discussed below.

Acid quenching in dissociated neurons. Dissociated neuronal cultures were prepared as described previously (Li et al., 2003). Cells were plated at $\sim 300$ cells $/ \mathrm{mm}^{2}$ and cultured for $7 \mathrm{~d}$ followed by infection with SEPGluR2 expressing Sindbis virus and allowed to express for $36 \mathrm{~h}$. Imaging was performed as described above, except only a single optical plane was captured every $15 \mathrm{~s}$ for $5 \mathrm{~min}$. Three baseline images were taken in ACSF, $\mathrm{pH}$ 7.4, followed by exposure to pH 5.5 ACSF [sodium bicarbonate replaced in equimolar amount with membrane impermeable acid (MES)]. Basal ACSF, pH 7.4, was then washed back through, for the remainder of the experiment. The "before" data were the average of the first two images, and the "after" data were the average of the last two images. Puncta were identified as bright spots, whereas dendrites were defined as the uniform fluorescent structures between puncta.

Immunofluorescence. Living slices with cells expressing SEP or enhanced GFP (eGFP)-GluR2 (both amino-terminally tagged) were imaged as described above. Slices were immediately fixed in $4 \%$ paraformaldehyde for $60 \mathrm{~min}$ at $4^{\circ} \mathrm{C}$ and washed three times with PBS for $20 \mathrm{~min}$. The slices were then incubated in blocking solution (10\% donor horse serum in PBS) for $1 \mathrm{~h}$ at room temperature. The fixed slices were then incubated in mouse monoclonal anti-GFP antibody (Roche Products, Welwyn Garden City, UK) at $2 \mathrm{ng} / \mathrm{ml}$ in blocking solution overnight at $4^{\circ} \mathrm{C}$, followed by three $20 \mathrm{~min}$ washes with PBS at room temperature. The slices were then incubated in biotinylated goat anti-mouse IgG secondary antibody (Vector Laboratories, Burlingame, CA) at $2 \mathrm{ng} / \mu \mathrm{l}$ for $2 \mathrm{~h}$ at room temperature, followed by incubation in Texas Red Avidin (Vector Laboratories) at $15 \mathrm{ng} / \mu \mathrm{l}$ for $2 \mathrm{~h}$ in the dark at room temperature. The same dendritic regions previously imaged were identified using branch landmarks and reimaged to capture the fixed green (receptor) and red (anti-GFP, surface receptor) signals. This anti-GFP antibody can also recognize SEP.

Electrophysiology. In experiments to test the effect of chemLTP on amplitude of transmission, slices were prepared as described above, and a glass field recording electrode (resistance, 0.5-1.5 $\mathrm{M} \Omega$ ) filled with ACSF was inserted into the cell body layer of the CA1 region. Synaptic transmission was evoked using a two-contact $\mathrm{Pt} / \mathrm{Ir}$ cluster electrode (Frederick Haer, Bowdoinham, ME) stimulating electrode placed $\sim 300$ $\mu \mathrm{m}$ down the apical dendrite and displaced horizontally $200 \mu \mathrm{m}$. Test pulses were delivered every $30 \mathrm{~s}$. During the $16 \mathrm{~min}$ chemLTP induction and $20 \mathrm{~min}$ after, no test pulses were delivered. In these slices, no cut was made at the CA2 region, because bursting during chemLTP induction is required (Otmakhov et al., 2004).

To monitor synaptic delivery of recombinant GluR1, slices were infected with a Sindbis virus expressing eGFP-GluR1 (Shi et al., 2001). Twenty-four to $36 \mathrm{~h}$ after infection, chemLTP was induced for $16 \mathrm{~min}$ in a perfusion chamber. After wash of the chemLTP solution, slices were transferred to a chamber under a dissecting microscope and cut in the CA2 region to prevent subsequent stimulus-evoked bursting. Slices were moved to the recording chamber. Bath solution $\left(27 \pm 1.5^{\circ} \mathrm{C}\right)$ in the recording chamber contained the following (in $\mathrm{mM}$ ): $119 \mathrm{NaCl}, 2.5 \mathrm{KCl}$, $4 \mathrm{CaCl}_{2}, 4 \mathrm{MgCl}_{2}, 26 \mathrm{NaHCO}_{3}, 1 \mathrm{NaH}_{2} \mathrm{PO}_{4}, 11$ glucose, and 0.1 picrotoxin, $\mathrm{pH} 7.4$, and gassed with $5 \% \mathrm{CO}_{2} / 95 \% \mathrm{O}_{2}$. TTX (1 nM) was included to prevent bursting. Patch recording pipettes (3-5 M $\Omega$ ) contained the following (in mM): 115 cesium methanesulfonate, $20 \mathrm{CsCl}, 10$ HEPES, $2.5 \mathrm{MgCl}_{2}$, $4 \mathrm{Na}_{2} \mathrm{ATP}, 0.4 \mathrm{Na}_{3} \mathrm{GTP}, 10$ sodium phosphocreatine, 0.6 EGTA, and 0.1 spermine, pH 7.25. Whole-cell recordings were obtained with Axopatch-1D amplifiers (Molecular Devices, Foster City, CA). Evoked EPSC amplitudes were recorded at -60 and $+40 \mathrm{mV}$ from alternating infected and uninfected cells. Recordings were made within a period of $20 \mathrm{~min}$ to $2 \mathrm{~h}$ after chemLTP induction. Rectification is defined as the ratio of current at $-60 /+40 \mathrm{mV}$ (Shi et al., 2001).

Conventional LTP was induced by pairing postsynaptic depolarization at $0 \mathrm{mV}$ with presynaptic stimulation at $3 \mathrm{~Hz}$ for $1.5 \mathrm{~min}$.

To monitor spontaneous activity during chemLTP induction, cell- 
attached recordings were obtained from organotypic slices (with no cut at $\mathrm{CA} 2$ region) at $30^{\circ} \mathrm{C}$ using the Cs-based pipette solution described above. Pairs of CA3 and CA1 pyramidal neurons were sampled in current-clamp mode at $1 \mathrm{kHz}$. Continuous recordings spanned a $5 \mathrm{~min}$ baseline followed by the $16 \mathrm{~min}$ chemLTP induction and a $10 \mathrm{~min}$ period immediately after chemLTP induction.

Quantitative image analysis. Spines were analyzed using custom software written in MatLab. All analyses were conducted blind to the receptor being expressed. For each experiment, projection images of 40-60 consecutive z-series sections were generated for each time point. Spines were identified using the tDimer channel, and rectangular regions of interest (ROIs) were manually positioned to fully cover each spine. All spines identified in the first time point were followed for all of the subsequent time images, and thus the choice was blind with respect to the outcome. Individual spines were numbered and followed in a time-lapse recording. When the identity of a protrusion was unclear (for instance, two spines appear as one), the specific spine was not included in the analysis. In addition, no effort was made to analyze spines emerging below or above the dendrite, because the TPLSM resolution of these is compromised. It is also possible that many small structures were not detected, although point spread function-limited structures were observed. Dendrite ROIs were placed at the base of each spine centered on the dendrite with approximately the same area as the corresponding spine ROI. Total integrated fluorescence (in arbitrary units) for both green and red channels were computed for each section in a stack. Background and spillover (from the other channel) fluorescence were subtracted to generate a background and spillover subtracted integrated fluorescence value for each channel as a function of depth. The potential effects of Forster resonance energy transfer (FRET) between SEP and tDimer were not compensated given the highly unlikely occurrence of FRET across a membrane between nonlinked fluorophores. Z-boundaries were defined by the full-width at half-maximum of the tDimer channel ( $\mathrm{X}$ and $\mathrm{Y}$ boundaries defined by the ROI). Red and green fluorescence was then integrated within these boundaries (supplemental Fig. 1, available at www.jneurosci.org as supplemental material). For dendrite ROIs, the mean pixel fluorescence (rather than integrated fluorescence) was taken within these boundaries to negate any effect that alterations in the size of the ROI would have. Only pixels that were $>3$ SDs above background were included in the average. Significance was determined by bootstrap and $t$ test of data after chemLTP induction versus baseline.

Enrichment of receptors on spines is defined as (spine green/spine red fluorescence)/(dendrite green/dendrite red fluorescence). This technique is used as a relative not absolute means of determining enrichment. Data from each group were plotted as a cumulative distribution; significant differences were determined by a Kolmogorov-Smirnov test. For all chemLTP experiments, the fluorescence of each ROI was normalized to the fluorescence of that ROI at the -10 min time point. All ROIs for every cell in a given condition were averaged for each time point. Statistical significance for time-lapse images of spines was determined by bootstrap and $t$ test. Fold change (receptor or volume) was determined by averaging the values after chemLTP induction and dividing by the average of the values before chemLTP induction. This was done individually for each ROI. For absolute volume change, each spine volume was normalized by the average of all spines imaged on that cell. The difference was taken between the mean after and mean before induction for each individual spine.

For autocorrelation and Fourier analysis, data were first arrayed as the ROIs appear in linear order along the dendrite. The autocorrelation value for each branch was calculated at relative distances 1-5. A distance of 1 corresponds to neighboring spines, whereas a distance of 2 corresponds to every second spine and so on. This was then compared with the value obtained by averaging the result of 10,000 random shuffles of the data order. Only an original value either 3 SDs above or below the random shuffle result was considered significant. For the Fourier analysis, the data were arrayed as described above, and power versus frequency spectra were generated for each variable tested for each branch. Peaks were considered significant if they were $>3$ SDs above background. a
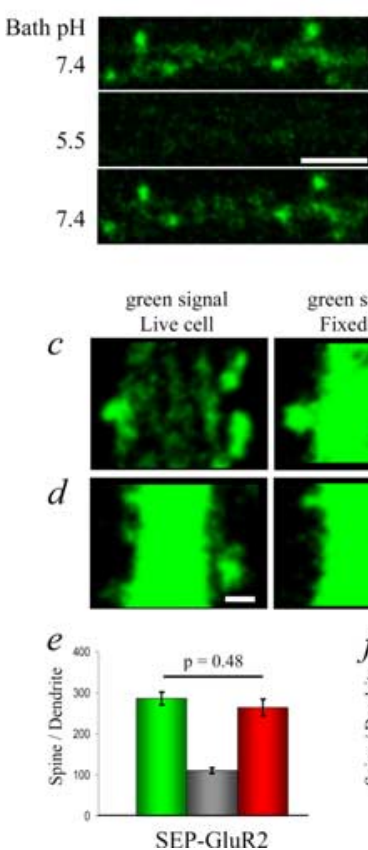

SEP-GluR2 b

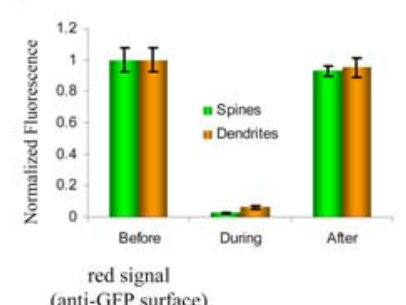
(anti-GFP surface) Fixed cell

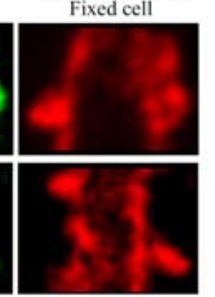

SEP-GluR2

eGFP-GluR2

Figure 1. Super ecliptic pHluorin functions to specifically mark surface receptors. $\boldsymbol{a}, \boldsymbol{b}$, Dissociated hippocampal cultures were infected with Sindbis virus expressing SEP-GluR2 and imaged using two-photon laser-scanning microscopy. Cells were perfused with pH 7.4 ACSF followed by a brief exposure to $\mathrm{pH} 5.5$ and then returned to $\mathrm{pH}$ 7.4. $\boldsymbol{a}$, Representative image of a dendrite and puncta before, during, and after exposure. Images are a single Z-section. $\boldsymbol{b}$, Quantification of puncta and dendrite intensities before, during, and after exposure normalized to baseline. $n=3$ cells, 30 puncta, and 30 dendritic regions. Scale bar, $5 \mu \mathrm{m}$. c-f, Organotypic hippocampal CA1 pyramidal cells expressing fluorescent-tagged GluR2 were imaged. The same cells were imaged live, after fixation (nonpermeabilizing conditions), and after immunostained with surface anti-GFP, as indicated. $\boldsymbol{c}$, Cell expressing SEP-tagged GluR2. $\boldsymbol{d}$, Cell expressing eGFP-tagged GluR2. $\boldsymbol{e}, \boldsymbol{f}$, Bar graph of the mean ratio of spine-integrated fluorescence to dendrite mean fluorescence calculated for spine and dendrite box pairs for neurons in several conditions. $\boldsymbol{e}$, Spine/dendrite for cells expressing SEP-GluR2 ( $n=80$ spines; 3 cells). $\boldsymbol{f}$, Spine/ dendrite for cells expressing eGFP-GluR2 ( $n=47$ spines; 3 cells). Scale bar, $1 \mu \mathrm{m}$. Error bars represent SEM.

\section{Results}

\section{pH-sensitive GFP to tag surface receptors}

To monitor surface dynamics of glutamate receptors, we tagged receptor subunits on the $\mathrm{N}$ terminus with a $\mathrm{pH}$-sensitive form of GFP (SEP) (Miesenbock and Rothman, 1998) (G. Miesenbock, personal communication). The resulting receptor should display fluorescence when on the surface membrane (which exposes SEP to neutral environment) and should be mostly nonfluorescent when trapped in intracellular compartments (which have lower pH) (Anderson et al., 1984). Thus, unlike an eGFP-tagged receptor, an SEP-tagged receptor should capture the exocytosis of the receptor from intracellular compartment onto the surface.

To test whether such a strategy is valid, we first expressed SEP-GluR2 in dissociated hippocampal neurons using Sindbis virus. Previous electrophysiological experiments indicate that this molecule is readily delivered and incorporated onto the surface of synapses (Shi et al., 2001). To determine the surface fraction of SEP-GluR2 fluorescence, we rapidly and reversibly acidified the extracellular solution using a membrane impermeable acid to quench only surface fluorescence (Fig. $1 a, b$ ). During brief exposure to acid, $94.6 \pm 0.9 \%$ of fluorescence on puncta and $87.4 \pm 2.1 \%$ of fluorescence on dendrites was reversibly quenched (Fig. 1b). This indicates that most of the SEP fluorescence is derived from surface receptors. 
$a$

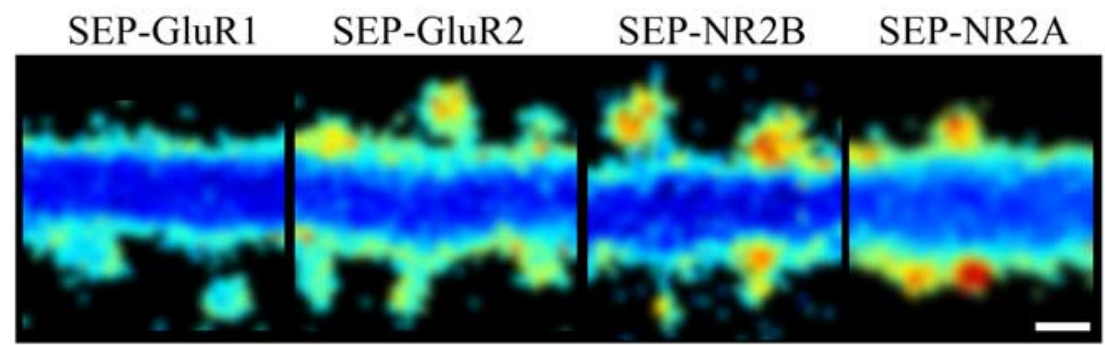

$b$
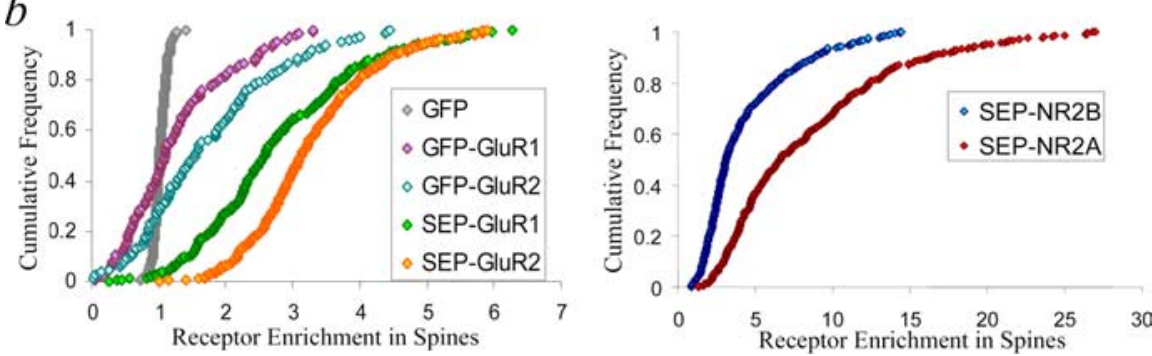

Figure 2. Spine enrichment of SEP-tagged receptors is different for each receptor subtype. Spine and dendrite integrated fluorescence collected from CA1 pyramidal cells expressing tDimer dsRed along with SEP-tagged GluR1, GluR2, NR2A, or NR2B. Enrichment is the ratio of spine green/red fluorescence to dendrite green/red fluorescence. $\boldsymbol{a}$, Ratio images (green/red) of cells expressing tDimer dsRed and indicated SEP-tagged receptor. Blue depicts low receptor density, and red depicts high density. $\boldsymbol{b}$, Cumulative distribution of enrichment for spines expressing tDimer dsRed along with the indicated SEP-tagged receptor. GFP, $n=$ 188 spines, five cells; GFP-GluR1, $n=136$ spines, six cells; GFP-GluR2, $n=122$ spines, five cells; SEP-GluR1, $n=200$ spines, three cells; SEP-GluR2, $n=175$ spines, three cells; SEP-NR2A, $n=220$ spines, seven cells; SEP-NR2B, $n=204$ spines, five cells. Scale bar, $1 \mu \mathrm{m}$.

We next wanted to determine whether SEP fluorescence from CA1 neurons in organotypic hippocampal slice cultures was also primarily from surface receptors. For this experiment, we could not use acid quenching, because the time required for bathapplied acid to permeate a slice was too long. We therefore decided to use surface antibody labeling of recombinant receptors and measure the correlation between the fluorescence pattern of the antibody and the recombinant receptor.

Neurons expressing SEP-GluR2 via biolistic delivery (see Materials and Methods) displayed greater fluorescence on the edges of large dendrites compared with their center (Fig. 1c), as expected if SEP-GluR2 fluorescence originated from tagged receptors on the dendritic surface. This pattern was not seen in neurons expressing GluR2 amino-terminally tagged with eGFP (eGFP-GluR2) (Fig. 1d) and indicates a reserve of recombinant AMPARs in intracellular compartments, consistent with a significant number of intracellular endogenous receptors (Petralia and Wenthold, 1992; Baude et al., 1995; Shi et al., 1999; Park et al., 2004). Images obtained from the same neurons after fixation, which collapses the $\mathrm{pH}$ gradient, showed a similar fluorescence pattern for SEP-GluR2 and eGFP-GluR2. Thus, the difference in live tissue was attributable to the $\mathrm{pH}$ of the endosomal system and not localization differences caused by the fluorophore. We also immunostained the same neurons for GFP under nonpermeabilizing conditions. We used a Texas Red-linked secondary antibody. (Fig $1 c, d$ ). In this case, the distribution of Texas Red fluorescence, a marker of surface recombinant GluR2, appeared like the live SEP fluorescence and unlike eGFP fluorescence (Fig. $1 e, f)$. We conclude that SEP can be used to mark surface-labeled receptors.

\section{Receptor subtypes display distinct surface distribution patterns}

We next examined the distribution of SEP-tagged receptors on dendritic spines and nearby dendritic segments. To demarcate dendritic anatomy, we coexpressed T1dimer dsRed (Campbell et al., 2002), a protein that shows distribution in dendrites and spines similar to that of eGFP (Fig. $2 b$ ) and can be optically separated from SEP. Spatial distribution of SEPtagged receptor signal, displayed in a manner that is normalized for volume (pixelwise green/red fluorescence displayed in pseudocolor; see Materials and Methods), is shown in Figure $2 a$. The signal for all receptors was greater at the edges of dendrites, indicating that primarily recombinant surface receptors displayed fluorescence.

To compare the relative amounts of receptor on spines for the different receptor subtypes, we calculated a spine enrichment value (volume normalized receptor fluorescence on spine divided by volume normalized receptor fluorescence on underlying dendrite; see Materials and Methods). This measure is chosen to permit comparisons independent of expression levels (supplemental Fig. 3, available at www.jneurosci.org as supplemental material), although it is sensitive to changes in spine size and dendritic diameter (because normalization is by spine volume and dendrite size). The enrichment of the SEP signal at spines was different for the four glutamate receptors (Fig. $2 b$ ). No difference was seen in spine size among cells expressing SEP-GluR1, SEPNR2A, and SEP-NR2B, indicating that these receptors display different trafficking under basal conditions. Expression of SEPGluR2 did reduce spine size by 15\% (Passafaro et al., 2003), which can only partially explain the $40 \%$ difference in enrichment between SEP-GluR1 and SEP-GluR2. No difference was seen in dendritic diameter between cells expressing any of the above SEP-tagged receptors. These results indicate that surface AMPARs and NMDARs are enriched on spines to varying degrees depending on the receptor subunit composition.

\section{LTP induction using a global protocol}

We wanted to determine whether LTP produced exocytosis or endocytosis or lateral movement of receptors on the surface of spines and dendrites. Standard LTP, induced by electrical stimulation of afferent fibers, is not optimally suited to optical studies, because it is difficult to stimulate reliably a large number of fibers that terminate onto the synapses in the field of view. We thus induced LTP by bath application of a solution that favors activation of NMDARs and globally drives neuronal cells to burst (Otmakhov et al., 2004). Simultaneous cell-attached patch recordings from CA1 and CA3 neurons indicated that application of LTP induction solution rapidly produced synchronous bursting $(\sim 1 \mathrm{~Hz})$ of all neurons in the slice (Fig. $3 a)$. Because in organotypic slices each synapse originates from a presynaptic cell body in the slice, this result indicates that each synapse observed during imaging is likely to receive burst activation during this protocol. We initially confirmed that this chemically induced form of LTP enhanced evoked synaptic transmission (Fig. 3a). We also showed, using electrophysiological tagging methods (Hayashi et al., 2000), that chemLTP drove recombinant GluR1 into synapses (Fig. $3 b$ ). And last, we showed that chemLTP led to increased 


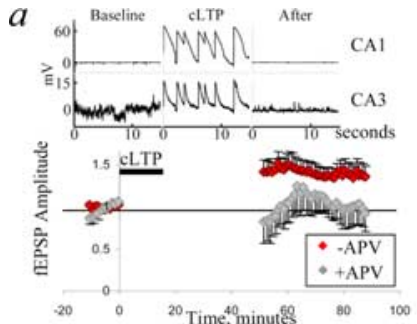

b
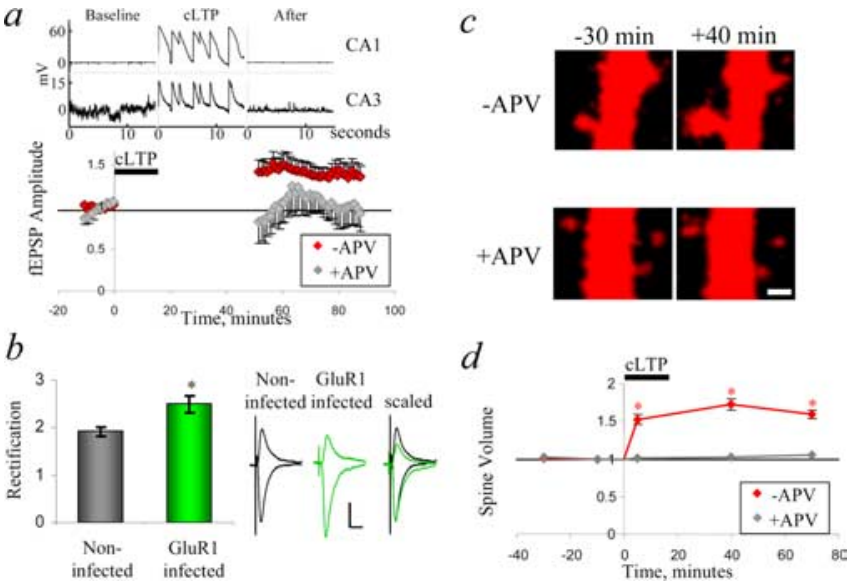

Figure 3. chemLTP mimics tetanus-induced LTP. a chemLTP (cLTP) drives global bursting and enhances synaptic transmission. Top, Fifteen second periods from simultaneous cellattached paired recording of a CA1 and CA3 pyramidal neuron before, during, and after chemLTP induction. Six of six paired recordings showed simultaneous activity. Bottom, Field potential recording of evoked synaptic transmission in organotypic hippocampal slice cultures of the CA1 region cell body layer. LTP-inducing solution was applied for $16 \mathrm{~min}$ as denoted by the black bar. Field potential amplitudes are plotted for slices exposed to LTP-inducing solution \pm APV $(-\mathrm{APV}, n=7 ;+\mathrm{APV}, n=4 ; p<0.01)$. The period of time from 0 to $40 \mathrm{~min}$ is not included because of population spikes that prevented accurate measurement of synaptic response. For + APV recordings, APV was present throughout the entire recording period. $\boldsymbol{b}$, chemLTP drives recombinant GluR1 into synapses. CA1 pyramidal cells infected with Sindbis virus expressing eGFP-GluR1. Evoked EPSC amplitudes were recorded at +40 and $-60 \mathrm{mV}$ after $20 \mathrm{~min}$ of recovery after chemLTP induction. Rectification denotes the ratio of current $(-60 /+40 \mathrm{mV}$; GluR1, $n=15$; control, $n=15 ; p=0.01$ ). $\boldsymbol{c}$, $\boldsymbol{d}$, chemLTP (CLTP) drives spine growth. $\boldsymbol{c}$, CA1 hippocampal pyramidal neurons expressing tDimer dsRed and SEP-GluR1 (green channel not shown) via biolistic transfection. Images taken at $-30 \mathrm{~min}$ and +40 min relative to the induction of chemLTP either \pm APV are shown. Scale bar, $1 \mu \mathrm{m}$. $\boldsymbol{d}$, Mean integrated spine red fluorescence from cells in $c$. The black bar denotes chemLTP induction. ${ }^{*} p<0.01$ compared with baseline values. - APV, $n=200$ spines, three cells; + APV,$n=181$ spines, three cells. Error bars represent SEM.

spine size (Fig. $3 c, d$ ). These properties of chemLTP were blocked by APV (Fig. 3). These results complement those conducted by others (Otmakhov et al., 2004) and show that chemLTP displays key features of standard electrically induced LTP (Lisman, 2003).

\section{LTP induces GluR1 exocytosis}

We next examined the effect of chemLTP on surface dynamics of recombinant AMPARs and NMDARs while also monitoring morphological changes in spines. To monitor surface AMPARs, we measured the SEP fluorescence; for morphological changes, we measured the T1-dimer signal. Signals were integrated over multiple image stacks that fully captured structures (supplemental Fig. 1, available at www.jneurosci.org as supplemental material) (see Materials and Methods). First, to directly test for exocytosis, we calculated the total integrated SEP-GluR1 fluorescence from the entire dendrite and all attached spines in the image window (supplemental Fig. 2, available at www. jneurosci.org as supplemental material) before and after chemLTP. Here, we observed an $18 \pm 13 \%(n=4$ neurons; $p=$ 0.034) increase in fluorescence after chemLTP, indicating that intracellular organelles containing GluR1 receptors undergo exocytosis. This increase could not be the result of lateral diffusion from outside the image window, because we should have imaged the stretch of dendrite outside the image window with equal likelihood. Next, we analyzed spine and dendrite compartments separately to detect where GluR1 was accumulating on the neuronal surface (supplemental Fig. 1a, available at www.jneurosci.org as
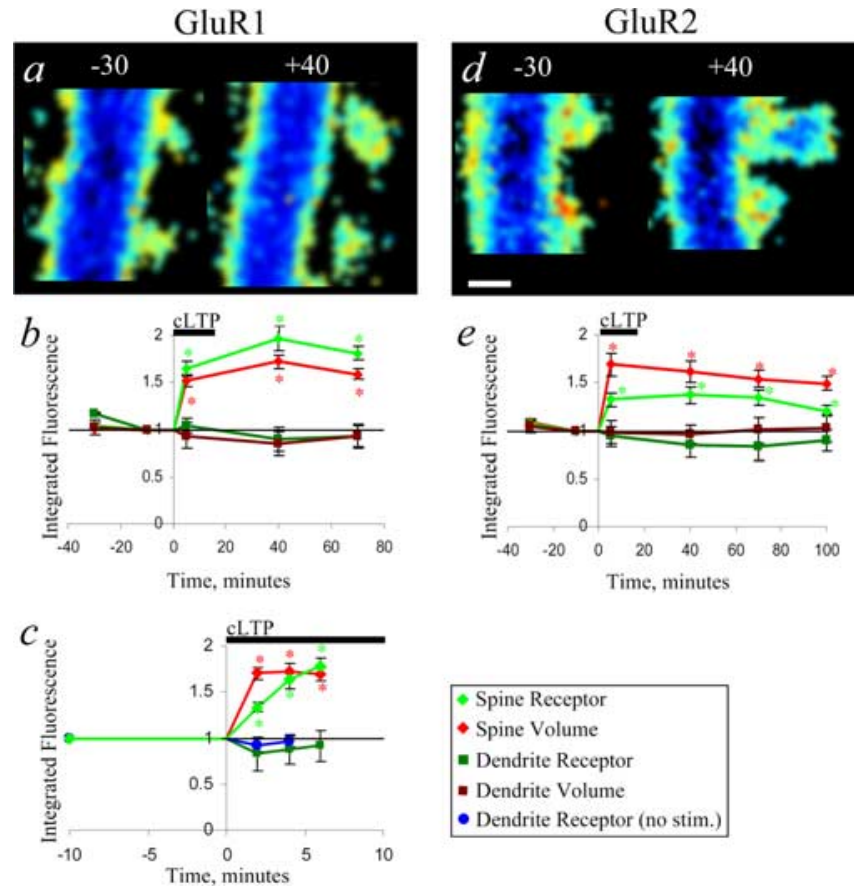

Figure 4. chemLTP drives SEP-GluR1 and SEP-GluR2 onto dendritic spines. $\boldsymbol{a}-\boldsymbol{c}$, CA1 pyramidal cells expressing tDimer dsRed and SEP-GluR1. $\boldsymbol{a}$, Ratio images (green receptor/red volume) at -30 and +40 min relative to chemLTP induction. $\boldsymbol{b}$, Integrated red (volume) and green (receptor) fluorescence for spines and dendrites ( $n=200$ spines, 3 cells). Each region of interest is normalized to its value at the $-10 \mathrm{~min}$ time point. The black bar denotes chemLTP (cLTP) induction. ${ }^{*} p<0.01$ relative to baseline. $c$, Spine integrated receptor and volume during chemLTP (cLTP) induction imaged every $2 \mathrm{~min} . n=144$ spines, four cells. Dendrite receptor \pm chemLTP-inducing drugs ( + chemLTP, $n=144$ regions, 4 cells; - chemLTP, $n=34$ regions, 5 cells). Values normalized as in $\boldsymbol{b}$. $\boldsymbol{d}, \boldsymbol{e}$, Cells expressing tDimer dsRed and SEP-GluR2. $\boldsymbol{d}$, Ratio images (green receptor/red volume) at -30 and +40 min relative to chemLTP induction. $\boldsymbol{e}$, Integrated red (volume) and green (receptor) fluorescence for spines and dendrites ( $n=175$ spines; 3 cells) normalized as in $\boldsymbol{b}$. ${ }^{*} p<0.01$. Scale bar, $1 \mu \mathrm{m}$. Error bars represent SEM.

supplemental material). Within 5 min after the initiation of chemLTP, the volume of spines and the SEP-GluR1 signal on spines increased (Fig. 4a,b). The enhanced spine SEP-GluR1 signal was long-lasting $(81 \pm 7.6 \%$ increase at $70 \mathrm{~min}$ after induction, the last time point examined). The chemLTP-induced increase in spine SEP-GluR1 was blocked by APV (data not shown). We observed little change $(-4 \pm 10 \%)$ in net dendritic signal (entire dendrite tiled with ROIs for analysis) (supplemental Fig. 2, available at www.jneurosci.org as supplemental material), suggesting no significant net shift of receptors from dendritic surface to spine surface (Fig. $4 b$ ). We also analyzed the dendritic edge between spines (supplemental Fig. $1 c$, available at www.jneurosci.org as supplemental material). Here, again, we observed no significant net shift in SEP-GluR1 fluorescence during chemLTP ( $+5 \pm 8 \% ; n=3$ neurons; 164 ROIs). Nevertheless, a small amount of lateral movement from dendrite to spines could be missed, because the dendrite contained more surface SEP-GluR1 (integrated dendritic SEP-GluR1/integrated spine SEP-GluR1 = 3.35) (supplemental Fig. 2, available at www.jneurosci.org as supplemental material). Although the exact site of exocytosis cannot be determined, we conclude that exocytosis of GluR1 occurs during chemLTP and that the net effect is a long-lasting increase in spine surface receptor content.

Spine enlargement precedes the majority of GluR1 exocytosis To examine the dynamics of SEP-GluR1 trafficking and morphological changes more closely, we conducted a faster acquisition 
series. Image stacks were obtained every 2 min after the start of the chemLTP protocol. The increase in spine volume obtained its maximum by the first image (i.e., the difference between spine volume at 2 min was not significantly different from the value at $6 \mathrm{~min} ; 2 \mathrm{~min}, 1.70 \pm 0.067 ; 6 \mathrm{~min}, 1.69 \pm 0.073 ; p=0.80)$. However, the SEP-GluR1 signal gradually increased on spines over the first $6 \mathrm{~min}$. The value at $2 \mathrm{~min}$ was significantly less than the value at $6 \mathrm{~min}(2 \mathrm{~min}, 1.33 \pm 0.05 ; 6 \mathrm{~min}, 1.78 \pm 0.09 ; p<$ 0.001 ) (Fig. 4c). This temporal dissociation indicates that distinct mechanisms control spine enlargement and receptor incorporation into spine surface.

In these faster acquisition experiments, we noted a transient small decrease in dendritic SEP-GluR1 signal below spines, but this change was not statistically different from a similar drop observed in time series in which no chemLTP stimulus was delivered. The decrease in dendritic signal is likely attributable to bleaching associated with more rapid imaging (Fig. 4c). These results argue against the possibility that the increase in spine SEPGluR1 is a result of a net shift of receptor from dendrite surface to spine surface. However, we cannot rule out the possibility that movement of GluR1 from dendritic surface to spine surface is balanced by movement from intracellular stores to the dendritic surface.

\section{GluR2 displays spine surface incorporation during LTP}

To determine whether GluR2 displayed a similar exocytosis phenotype to GluR1, we examined the effect of chemLTP on the dynamics of SEP-GluR2. First, we performed combined spine dendrite analysis (same as that for SEP-GluR1 in supplemental Fig. 2, available at www.jneurosci.org as supplemental material). Here, we saw no net increase in SEP-GluR2 fluorescence indicating no net exocytosis $(-13.9 \pm 5 \%)$. After induction of chemLTP, however, SEP-GluR2 fluorescence did increase at spines to a degree that was significantly smaller than the increase in spine volume (Fig. $4 d, e)(31 \pm 3.6 \%$ for SEP-GluR2 vs $58.9 \pm 4.9$ for T1-dimer; $p<0.001)$. By the last time point (100 min after initiation of chemLTP), the increase in spine SEP-GluR2 signal had fallen to $\sim 20 \%$ above baseline values. At all time points, the chemLTP-induced increase in SEP-GluR2 was significantly less than that of SEP-GluR1 ( $p<0.01$ for all time points).

\section{Little NMDA receptor trafficking during LTP}

The trafficking of NMDA receptors after LTP is not clear, although recent studies suggest that they can rapidly move in response to activity (Carroll and Zukin, 2002; Collingridge et al., 2004; Perez-Otano and Ehlers, 2004). To elucidate this issue, NMDA receptors were monitored after chemLTP in neurons expressing SEP-NR2B or SEP-NR2A. Expression of recombinant NR2A or NR2B subunits alone sufficed for synapse incorporation as determined using electrophysiological tagging techniques (Barria and Malinow, 2002) (supplemental Fig. 4, available at www.jneurosci.org as supplemental material). Because NR1 is an obligate subunit in functional NMDARs, we infer that the recombinant NR2 subunits heteromerize with endogenous NR1, which is known to be in excess in hippocampal neurons (Huh and Wenthold, 1999), permitting the tagged receptors to concentrate at synapses. After induction of chemLTP, neither receptor showed large changes, despite the increase in spine volume. SEPNR2B spine fluorescence decreased steadily after chemLTP induction reaching a $23 \%$ reduction by $70 \mathrm{~min}(p<0.001)$ (Fig. $5 a, b)$. SEP-NR2A showed no significant changes (Fig. $5 d, e$ ). Control experiments showed that expression of SEP-NR2A at 18-20 $\mathrm{d}$ in vitro permitted normal levels of electrophysiologically mea-
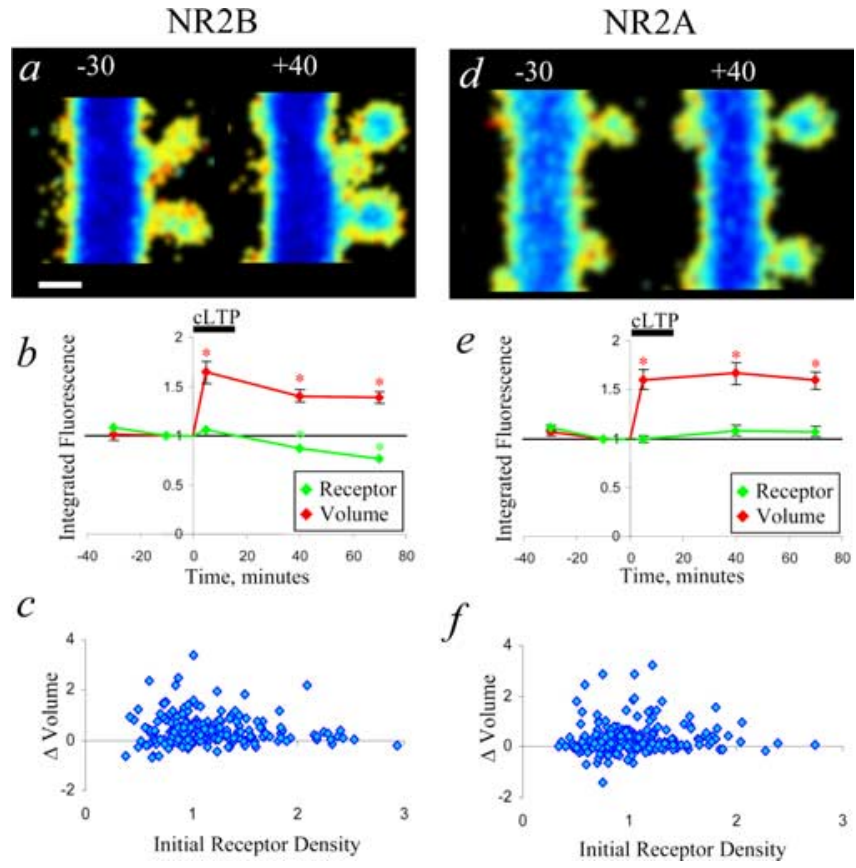

Figure 5. chemLTP removes spine SEP-NR2B but not SEP-NR2A. $\boldsymbol{a}-\boldsymbol{c}$, Cells expressing tDimer dsRed and SEP-NR2B. $\boldsymbol{a}$, Ratio images (green receptor/red volume) at -30 and +40 min relative to chemLTP induction. $\boldsymbol{b}$, Integrated red (volume) and green (receptor) fluorescence for spines ( $n=204$ spines; 5 cells) normalized as in Figure 4 . ${ }^{*} p<0.01$. c, Initial spine NR2B density verses spine $\Delta$ volume as in c. Scale bar, $1 \mu \mathrm{m} . \boldsymbol{d}-\boldsymbol{f}$, CA1 pyramidal cells expressing tDimer dsRed and SEP-NR2A. $\boldsymbol{d}$, Ratio images (green receptor/red volume) at -30 and +40 min relative to chemLTP induction. $\boldsymbol{e}$, Integrated red (volume) and green (receptor) fluorescence for spines ( $n=220$ spines; 7 cells). Normalization is as in Figure 4. The black bar denotes chemLTP induction. ${ }^{*} p<0.01$. $\boldsymbol{f}$, Initial spine NR2A density (mean green baseline -30 and $-10 \mathrm{~min} /$ mean red baseline -30 and $-10 \mathrm{~min}$ ) verses spine $\Delta$ volume [mean red after $(+5,+40$, and $+70 \mathrm{~min})-$ mean red before $(-30$ and $-10 \mathrm{~min})]$. CLTP, chemLTP. Error bars represent SEM.

sured LTP (supplemental Fig. 5, available at www.jneurosci.org as supplemental material). Because there was an increase in spine volume and no increase in NR2A or NR2B, their density on spines decreased.

\section{Receptor subtypes display distinct trafficking during LTP}

In Figure 6, we compare the effect of chemLTP on the different receptor subunits. For each spine, we calculated the fractional change in fluorescence after chemLTP by taking the average signal of all time points after chemLTP and dividing by the average signal of all time points before chemLTP. Cumulative distributions are displayed, showing that significant heterogeneity exists among spines for the dynamics of a given glutamate receptor. Despite this heterogeneity, each of the four subunits demonstrated significantly different effects: GluR1 showed the largest increase; GluR2 showed a modest increase; NR2A showed no net change; and NR2B showed a modest decrease. The spine morphological changes during chemLTP were statistically indistinguishable between cells expressing the four receptor subtypes, suggesting that overexpression of subunits did not have a detectable impact on their physiology. The different behaviors after chemLTP among the different subunits further support the view that distinct mechanisms control the dynamics of each receptor. In particular, the dynamics of receptors cannot be explained by a mechanism in which receptors passively follow changes in surface area. 

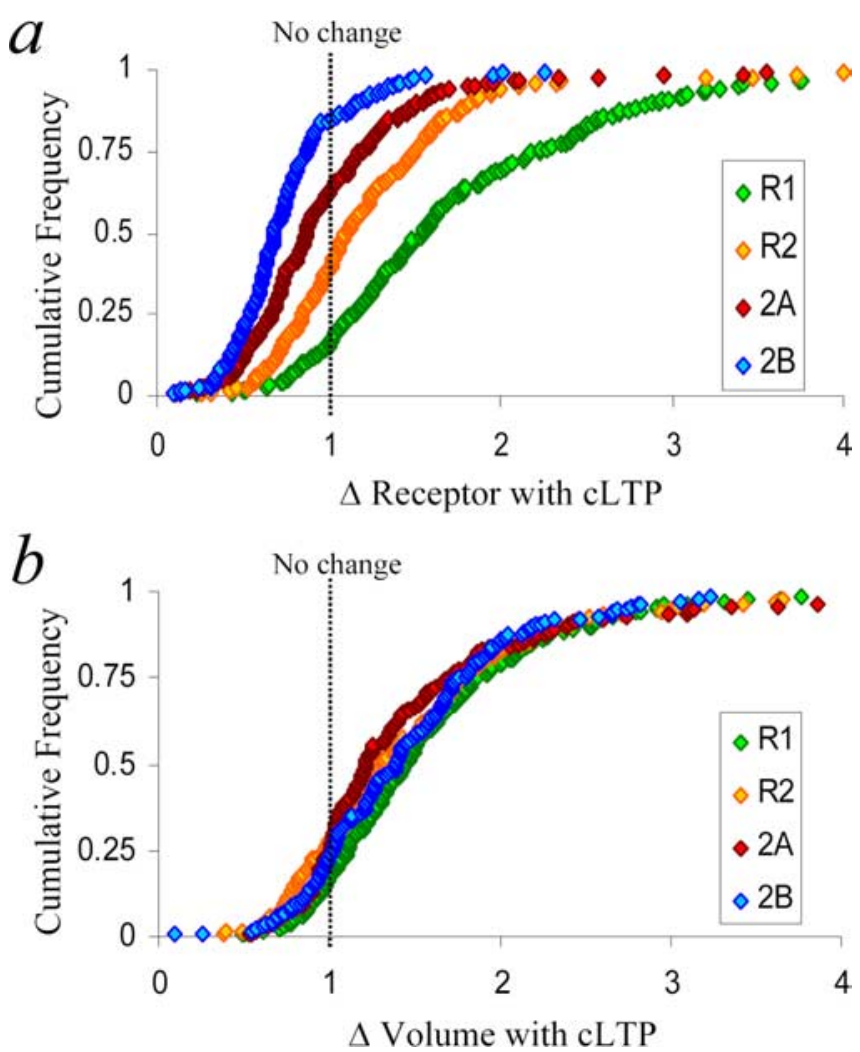

Figure 6. Changes in spine receptor and spine volume during chemLTP. $\boldsymbol{a}$, Cumulative frequency distribution for spine $\Delta$ receptor for cells expressing SEP-tagged GluR1, GluR2, NR2A, and NR2B. $\Delta$ Receptor defined as spine-integrated green (mean of fluorescence at $+5,+40$, and +70 min values) $/$ spine-integrated green (mean of fluorescence at -30 and $-10 \mathrm{~min}$ ). All time points relative to chemLTP induction are shown. $\boldsymbol{b}$, Cumulative frequency distribution for spine $\Delta$ volume. Analysis is as in $\boldsymbol{a}$ using spine red fluorescence. cLTP, chemLTP.

Spine enlargement is not correlated with initial spine state By examining individual spines undergoing a global LTP stimulus, we were able to address two outstanding issues in the field. First, we focused on the relationship between initial size or initial receptor content and the subsequent amount of enlargement. For instance, one may expect that spines that contain more NMDA receptors would show more enlargement. However, we saw no significant relationship between recombinant NMDAR density (Fig. $5 c, f$ ) or content (data not shown) and subsequent enlargement for a given spine. Furthermore, small spines and large spines demonstrated the same absolute increase in volume (Fig. $7 a, b)$ or receptor content (data not shown). We note that the fractional enlargement was larger for small spines, as reported previously (Fig. 7c) (Matsuzaki et al., 2004), but we believe this is only because a fixed increase will produce a larger fractional change in small spines.

\section{Spines enlarge as autonomous units not correlated with neighbors}

Next, we determined whether the changes in spines demonstrated regional correlations (or anticorrelations). We calculated autocorrelation values for changes in spine volume as a function of position along sections of dendrites. Autocorrelation functions for all variables measured (change in volume, SEP-GluR1, SEPGluR2, SEP-NR2A, and SEP-NR2B) showed no significant positive or negative local autocorrelation (see Materials and Methods), suggesting no regional effects. A similar analysis using Fourier transformations showed no statistically significant dom- inant frequency for any variable measured (supplemental Table 1, available at www.jneurosci.org as supplemental material). We thus conclude that with our methods of stimulation and recordings, we could detect neither positive nor negative local correlations. This means that for any measure of spine enlargement or receptor accumulation, distant spines were as likely as nearby spines to show similar enhanced values. Our findings are consistent with the view that spines behave as autonomous units (Zador et al., 1990; Matsuzaki et al., 2004).

\section{Discussion}

In this study, we examined structural modifications as well as glutamate receptor surface dynamics after plasticity-inducing stimuli. There has been debate regarding the magnitude and time course of structural changes during LTP (Desmond and Levy, 1983; Hosokawa et al., 1995; Sorra and Harris, 1998; Engert and Bonhoeffer, 1999; Maletic-Savatic et al., 1999; Toni et al., 1999; Ostroff et al., 2002; Lang et al., 2004; Matsuzaki et al., 2004; Okamoto et al., 2004). Here, we briefly drive bursting of endogenous synaptic activity in organotypic hippocampal slices to produce synaptic enhancement that mimics LTP (Otmakhov et al., 2004). This protocol produced an increase in spine size that was rapid and persistent. Some studies using electrical stimulation of axons to produce LTP have found slower (Engert and Bonhoeffer, 1999; Maletic-Savatic et al., 1999) or transient (Lang et al., 2004) increases in spine size. It may be that driving neurons to exhibit endogenous bursting patterns (Lisman, 1997) produces more robust effects. Using one chemical-induction protocol, investigators failed to detect changes in spine size (Hosokawa et al., 1995), perhaps because their labeling and imaging methods were not sufficiently sensitive, or because their electrical stimulation during the chemical treatment lead to potentiation of a subset of synapses.

Although the LTP protocol in this study uses epileptiform bursting to potentiate synapses, it differs significantly from seizure protocols. First, seizure protocols invariably induce subsequent persistent spontaneous bursting (Traub and Wong, 1982). In contrast, after removal of the chemLTP solution, we never observed spontaneous bursting. Second, some seizure protocols are only partially sensitive to APV (Morgan and Teyler, 2001), whereas the effects of chemLTP are completely sensitive to APV. Third, many seizure protocols result in little immediate spine changes followed later by spine loss (Nevander et al., 1985; Jiang et al., 1998; Swann et al., 2000; Mizrahi et al., 2004; Rensing et al., 2005; Wong, 2005). Here, we show rapid and persistent increases in spine size. Third, some epilepsy studies have observed dendritic beading and neuronal death, none of which we observed (Nevander et al., 1985; Swann et al., 2000; Wong, 2005). Finally, chemLTP drives GluR1 into synapses, as seen with pairinginduced LTP (Hayashi et al., 2000) and experience-driven plasticity (Takahashi et al., 2003; Rumpel et al., 2005). Together, although this chemLTP protocol uses endogenous epileptiform bursting to potentiate synapses, which may be at the strong end of the LTP-induction spectrum, its resulting LTP shares features of LTP induced by standard protocols and displays substantial differences to standard seizure models.

To test for exocytosis of glutamate receptors, we used SEP, a $\mathrm{pH}$-sensitive form of GFP introduced by Miesenbock and Rothman (1998). SEP undergoes a nearly 30-fold increase in fluorescence when it moves from $\mathrm{pH} 5.5$ to 7.4 . Such a $\mathrm{pH}$ and fluorescence gradient is expected between receptors residing in late endosomes in the dendrite (Park et al., 2004), which display low $\mathrm{pH}$ (Anderson et al., 1984), and the surface membrane. A similar 


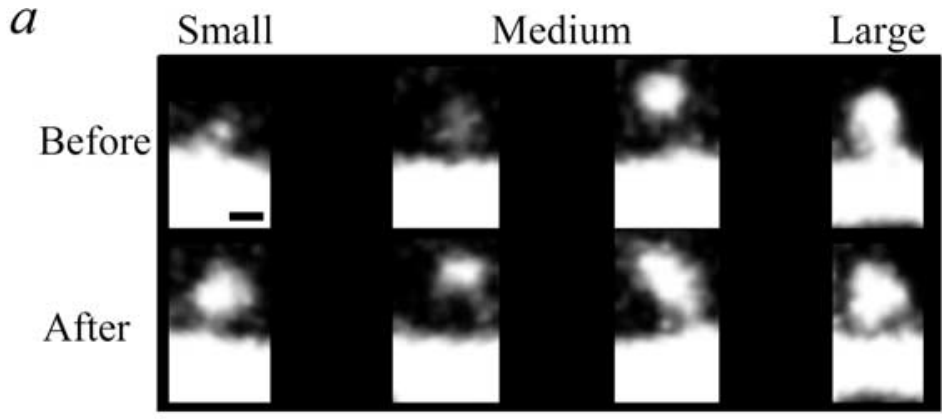

$b$

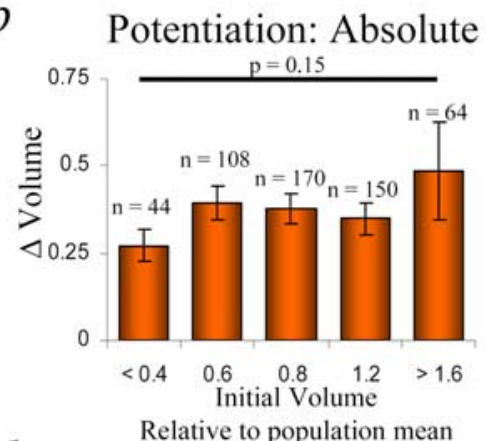

$d$

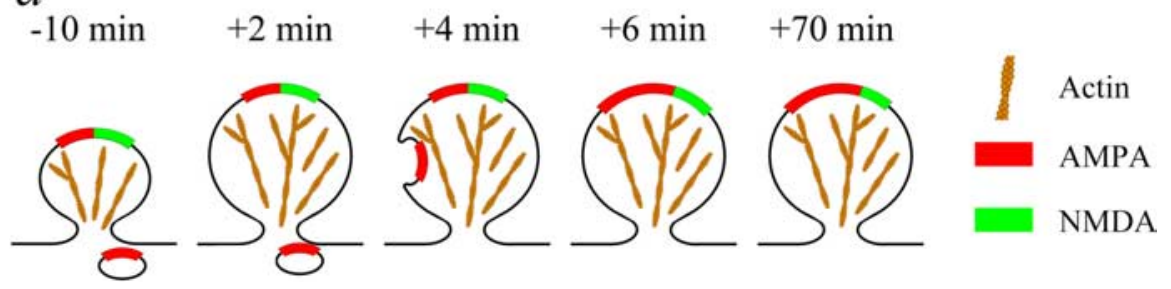

Figure 7. Spine enhancement is independent of initial spine size. $\boldsymbol{a}$, Example images of small, medium, and large spines before and after chemLTP induction. Scale bar, $1 \mu \mathrm{m} . \boldsymbol{b}$, Spine absolute $\Delta$ volume for all cells during chemLTP, normalized as in $\boldsymbol{a}$. Absolute $\Delta$ volume $=$ (mean of volume at $+5,+40$, and $+70 \mathrm{~min})-($ mean of volume at -30 and $-10 \mathrm{~min}) . c$, Spine fold $\Delta$ volume for all cells during chemLTP. Each spine is normalized by mean initial volume for each cell. Fold $\Delta$ volume $=$ (mean of fluorescence at $+5,+40$, and $+70 \mathrm{~min}$ )/(mean of fluorescence at -30 and $-10 \mathrm{~min}$ ). No data from cells expressing SEP-GluR2 were used in this analysis, because spines on those cells had a slightly reduced basal volume. $n=15$ cells. $\boldsymbol{d}$, Model of volume increase before receptor exocytosis during chemLTP. Error bars represent SEM.

strategy has recently been used to monitor endocytosis of GluR2 (Ashby et al., 2004). Here, we show that SEP, fused to the $\mathrm{N}$ terminus of glutamate receptors, can selectively mark the surface pool on spines and dendrites. After expression of individual glutamate receptor subunits tagged with SEP, they can be clearly demonstrated on dendritic spines. The accumulation on spines is different for the different receptors with SEP-NR2A $>$ SEPNR2B $>$ SEP-GluR2 $>$ SEP-GluR1. The differential accumulation in spines indicates different mechanisms controlling their localization. This is consistent with the view that the cytoplasmic termini of receptors, which differ for these four receptors, control their localization by interacting with different scaffolding proteins.

We find that within $2 \mathrm{~min}$, chemLTP induces stable structural enlargement of spines. In contrast, surface SEP-GluR1 appears slower, peaking at $\sim 6 \mathrm{~min}$. This temporal disparity suggests distinct cellular mechanisms underlying the two processes. For instance, if vesicular delivery of receptors into spines were responsible for the increased volume, then the volume and receptor signal would be expected to match temporally. We suggest that after LTP induction, there are events, likely mediated by rapid actin rearrangement (Fischer et al., 1998; Fukazawa et al., 2003; Okamoto et al., 2004) that are responsible for the increased spine volume and that occur before the receptor appears at the surface. Subsequently, receptors are delivered to the surface by fusion events (Park et al., 2004). It is possible that the cargo of this fused membrane provides receptors as well as proteins that stabilize the actin-induced structural growth.

After chemLTP, we see a net increase in SEP-GluR1 signal in regions containing dendritic segments and spines. This demonstrates that exocytosis of SEP-GluR1 occurs. We examined the potential movement of SEP-GluR1 from dendritic surface to spine surface, a process suggested in one model of LTP (Bredt and Nicoll, 2003). With slow (every $5 \mathrm{~min}$ ) or fast (every $2 \mathrm{~min}$ ) time resolution, we fail to see a decrease in dendritic SEP-GluR1 that matches the increased signal in the spine. It is possible that a movement of SEPGluR1 from dendrite surface to spine surface is compensated, in a quantitatively undetectable manner, by delivery of SEPGluR1 to the dendritic surface. We also performed auto correlation, variance, and Fourier analysis on the dendrite in an attempt to detect a chemLTP-induced shift of GluR1 on the dendritic surface. No consistent shift was found by any test (supplemental Table 1, available at www.jneurosci.org as supplemental material). Our results indicate that vesicles containing GluR1 receptors undergo exocytosis and reach spines within minutes, although the exact site of exocytosis and the path from intracellular sites to spine remain to be determined.

Previous studies have stressed the importance of GluR1 in LTP (Zamanillo et al., 1999; Hayashi et al., 2000) with no apparent requirement for GluR2 (Jia et al., 1996; Shi et al., 2001). Here, we find that chemLTP increases SEP-GluR2 content on spines, suggesting a previously unappreciated contribution of this receptor to LTP. However, the SEP-GluR2 increase is considerably less than that observed for SEP-GluR1. Furthermore, the SEP-GluR2 signal at spines may be perisynaptic and not synaptic, or it may represent a fraction of SEP-GluR2 that generates heteromeric receptors with endogenous GluR1 and therefore moves into synapses as GluR1 (Passafaro et al., 2001; Shi et al., 2001). We note that by 100 min after chemLTP induction, the SEP-GluR2 signal is almost back to baseline levels. It will be interesting to monitor SEP-GluR2 for longer periods, perhaps days, at which point one may expect to see increased SEP-GluR2 in spines as it exchanges for GluR1 at LTP-driven "slots" (Malinow and Malenka, 2002).

A number of electrophysiological studies have examined the increase in AMPA- and NMDA-mediated components of transmission after LTP. In general, an increase in AMPA-mediated transmission was detected, which strongly supports a postsynaptic modification in transmission after LTP (Kauer et al., 1988; Muller et al., 1988). Here, we find a large increase in surface AMPAR with no increase in surface NMDAR content on spines, providing independent support for the electrophysiological ob- 
servations. NR2B content decreases after chemLTP. Thus, as with longer stimuli, such as $2 \mathrm{~h}$ of visual experience (Quinlan et al., 1999) or learning (Quinlan et al., 2004), acute stimuli can lead to rapid reduction in NR2B surface content. Reduction of NR2B at synapses may decrease subsequent plasticity (Quinlan et al., 2004; Barria and Malinow, 2005).

Recent studies have examined interactions between nearby spines during plasticity (Fonseca et al., 2004; Matsuzaki et al., 2004). In this study, we deliver a global stimulus and examine the behavior of a large number of spines that cover dendritic segments $\sim 70-100 \mu \mathrm{m}$ in length. We considered two possible scenarios. In one case, potentiation may occur regionally, if there were some synergy between nearby spines. Alternatively, one may expect that nearby spines compete for "potentiation" molecules (Fonseca et al., 2004), in which case there may be anticorrelation between spines or regions. We performed autocorrelation analyses by examining the potential correlation between spines at different distances and saw no significant positive or negative correlation. We also performed a Fourier analysis in an attempt to detect any global patterns in the enlargement. No signal above a random distribution was found. This may indicate that spines act as independent units (Zador et al., 1990; Matsuzaki et al., 2004) or that we are not able to detect interspine interactions with this experimental paradigm, in which spines along the dendrite were activated more homogeneously.

We also examined whether the level of potentiation (as measured by surface AMPA receptors or spine size) depends on the initial value of any of the optical parameters measured. When normalized to initial size, we confirm that small spines show larger fractional increases than large spines (Matsuzaki et al., 2004). However, if measured as an absolute increase (in volume or AMPARs), we find that the potentiation does not depend on the initial value: small spines and large spines provide similar amounts of increase. One possible interpretation is that the magnitude of LTP is determined by the AMPA receptor load of intracellular membrane, and that this load is independent of spine size. Interestingly, the level of spine enlargement was also not correlated to recombinant NMDAR content. This observation may reflect the possibility that our stimulus protocol is sufficiently suprathreshold to drive a maximal modification of spines. We conclude that the modification of spines can be independent of their initial size and NMDAR content.

In conclusion (see model in Fig. 7), we find that LTP induces a rapid structural increase that is followed within minutes by spine surface accumulation of AMPA receptors. Spine surface incorporation of GluR1 occurs by exocytosis from intracellular sites, although the path remains to be identified. Spine surface delivery of GluR2 is less than GluR1 and decays. NR2A content changes little, whereas NR2B content decreases. With chemLTP, spines behave autonomously: potentiation levels are independent of initial spine size, receptor content, or location relative to neighbors. These results demonstrate multiple distinct mechanisms during LTP, controlling spine structural changes as well as trafficking of different glutamate receptors.

\section{References}

Anderson RGFJ, Goldstein JL, Brown MS (1984) Visualization of acidic organelles in intact cells by electron microscopy. Proc Natl Acad Sci USA 81:4838-4842.

Arnold D, Feng L, Kim J, Heintz N (1994) A strategy for the analysis of gene expression during neural development. Proc Natl Acad Sci USA 91:9970-9974.

Ashby MCDLRS, Ralph GS, Uney J, Collingridge GL, Henley JM (2004) Removal of AMPA receptors (AMPARs) from synapses is preceded by transient endocytosis of extrasynaptic AMPARs. J Neurosci 24:5172-5176.

Barria A, Malinow R (2002) Subunit-specific NMDA receptor trafficking to synapses. Neuron 35:345-353.

Barria A, Malinow R (2005) NMDA receptor subunit composition controls synaptic plasticity by regulating binding to CaMKII. Neuron 48:289-301.

Baude A, Nusser Z, Molnar E, McIlhinney RA, Somogyi P (1995) Highresolution immunogold localization of AMPA type glutamate receptor subunits at synaptic and non-synaptic sites in rat hippocampus. Neuroscience 69:1031-1055.

Bliss TV, Lomo T (1973) Long-lasting potentiation of synaptic transmission in the dentate area of the anaesthetized rabbit following stimulation of the perforant path. J Physiol (Lond) 232:331-356.

Bredt DS, Nicoll RA (2003) AMPA receptor trafficking at excitatory synapses. Neuron 40:361-379.

Burgess TL, Kelly RB (1987) Constitutive and regulated secretion of proteins. Annu Rev Cell Biol 3:243-293.

Campbell RETO, Palmer AE, Steinbach PA, Baird GS, Zacharias DA, Tsien RY (2002) A monomeric red fluorescent protein. Proc Natl Acad Sci USA 99:7877-7882.

Carroll RC, Zukin RS (2002) NMDA-receptor trafficking and targeting: implications for synaptic transmission and plasticity. Trends Neurosci 25:571-577.

Collingridge GL, Isaac JT, Wang YT (2004) Receptor trafficking and synaptic plasticity. Nat Rev Neurosci 5:952-962.

Desmond NL, Levy WB (1983) Synaptic correlates of associative potentiation/depression: an ultrastructural study in the hippocampus. Brain Res 265:21-30.

Engert F, Bonhoeffer T (1999) Dendritic spine changes associated with hippocampal long-term synaptic plasticity. Nature 399:66-70.

Fischer M, Kaech S, Knutti D, Matus A (1998) Rapid actin-based plasticity in dendritic spines. Neuron 20:847-854.

Fonseca R, Nagerl UV, Morris RG, Bonhoeffer T (2004) Competing for memory: hippocampal LTP under regimes of reduced protein synthesis. Neuron 44:1011-1020.

Fukazawa YSY, Ozawa F, Ohta Y, Mizuno K, Inokuchi K (2003) Hippocampal LTP is accompanied by enhanced F-actin content within the dendritic spine that is essential for late LTP maintenance in vivo. Neuron $38: 447-460$.

Gandhi SPSC (2003) Three modes of synaptic vesicular recycling revealed by single-vesicle imaging. Nature 423:607-613.

Harris KM, Kater SB (1994) Dendritic spines: cellular specializations imparting both stability and flexibility to synaptic function. Annu Rev Neurosci 17:341-371.

Hayashi Y, Shi SH, Esteban JA, Piccini A, Poncer JC, Malinow R (2000) Driving AMPA receptors into synapses by LTP and CaMKII: requirement for GluR1 and PDZ domain interaction. Science 287:2262-2267.

Hosokawa T, Rusakov DA, Bliss TV, Fine A (1995) Repeated confocal imaging of individual dendritic spines in the living hippocampal slice: evidence for changes in length and orientation associated with chemically induced LTP. J Neurosci 15:5560-5573.

Huh KH, Wenthold RJ (1999) Turnover analysis of glutamate receptors identifies a rapidly degraded pool of the $\mathrm{N}$-methyl-D-aspartate receptor subunit, NR1, in cultured cerebellar granule cells. J Biol Chem 274:151-157.

Jia Z, Agopyan N, Miu P, Xiong Z, Henderson J, Gerlai R, Taverna FA, Velumian A, MacDonald J, Carlen P, Abramow-Newerly W, Roder J (1996) Enhanced LTP in mice deficient in the AMPA receptor GluR2. Neuron 17:945-956.

Jiang M, Lee CL, Smith KL, Swann JW (1998) Spine loss and other persistent alterations of hippocampal pyramidal cell dendrites in a model of earlyonset epilepsy. J Neurosci 18:8356-8368.

Johnston D, Christie BR, Frick A, Gray R, Hoffman DA, Schexnayder LK, Watanabe S, Yuan LL (2003) Active dendrites, potassium channels and synaptic plasticity. Philos Trans R Soc Lond B Biol Sci 358:667-674.

Kauer JA, Malenka RC, Nicoll RA (1988) A persistent postsynaptic modification mediates long-term potentiation in the hippocampus. Neuron 1:911-917.

Lang CBA, Zablow L, Kandel ER, Siegelbaum SA, Zakharenko SS (2004) Transient expansion of synaptically connected dendritic spines upon induction of hippocampal long-term potentiation. Proc Natl Acad Sci USA 101:16665-16670. 
Li B, Otsu Y, Murphy TH, Raymond LA (2003) Developmental decrease in NMDA receptor desensitization associated with shift to synapse and interaction with postsynaptic density-95. J Neurosci 23:11244-11254.

Lisman J (2003) Long-term potentiation: outstanding questions and attempted synthesis. Philos Trans R Soc Lond B Biol Sci 358:829-842.

Lisman JE (1997) Bursts as a unit of neural information: making unreliable synapses reliable. Trends Neurosci 20:38-43.

Lledo PM, Zhang X, Sudhof TC, Malenka RC, Nicoll RA (1998) Postsynaptic membrane fusion and long-term potentiation. Science 279:399-403.

Maletic-Savatic M, Malinow R, Svoboda K (1999) Rapid dendritic morphogenesis in CA1 hippocampal dendrites induced by synaptic activity. Science 283:1923-1927.

Malinow R, Malenka RC (2002) AMPA receptor trafficking and synaptic plasticity. Annu Rev Neurosci 25:103-126.

Matsuzaki MHN, Ellis-Davies GC, Kasai H (2004) Structural basis of longterm potentiation in single dendritic spines. Nature 429:761-766.

Mayer ML, Armstrong N (2004) Structure and function of glutamate receptor ion channels. Annu Rev Physiol 66:161-181.

Miesenbock GDAD, Rothman JE (1998) Visualizing secretion and synaptic transmission with $\mathrm{pH}$-sensitive green fluorescent proteins. Nature 394:192-195.

Mizrahi A, Crowley JC, Shtoyerman E, Katz LC (2004) High-resolution in vivo imaging of hippocampal dendrites and spines. J Neurosci 24:3147-3151.

Monyer H, Burnashev N, Laurie DJ, Sakmann B, Seeburg PH (1994) Developmental and regional expression in the rat brain and functional properties of four NMDA receptors. Neuron 12:529-540.

Morgan SL, Teyler TJ (2001) Epileptic-like activity induces multiple forms of plasticity in hippocampal area CA1. Brain Res 917:90-96.

Morris RG, Moser EI, Riedel G, Martin SJ, Sandin J, Day M, O'Carroll C (2003) Elements of a neurobiological theory of the hippocampus: the role of activity-dependent synaptic plasticity in memory. Philos Trans R Soc Lond B Biol Sci 358:773-786.

Muller D, Joly M, Lynch G (1988) Contributions of quisqualate and NMDA receptors to the induction and expression of LTP. Science 242:1694-1697.

Nevander G, Ingvar M, Auer R, Siesjo BK (1985) Status epilepticus in welloxygenated rats causes neuronal necrosis. Ann Neurol 18:281-290.

Okamoto K, Nagai T, Miyawaki A, Hayashi Y (2004) Rapid and persistent modulation of actin dynamics regulates postsynaptic reorganization underlying bidirectional plasticity. Nat Neurosci 7:1104-1112.

Ostroff LE, Fiala JC, Allwardt B, Harris KM (2002) Polyribosomes redistribute from dendritic shafts into spines with enlarged synapses during LTP in developing rat hippocampal slices. Neuron 35:535-545.

Otmakhov N, Khibnik L, Otmakhova N, Carpenter S, Riahi S, Asrican B, Lisman J (2004) Forskolin-induced LTP in the CA1 hippocampal region is NMDA receptor dependent. J Neurophysiol 91:1955-1962.

Park M, Penick EC, Edwards JG, Kauer JA, Ehlers MD (2004) Recycling endosomes supply AMPA receptors for LTP. Science 305:1972-1975.

Passafaro M, Piech V, Sheng M (2001) Subunit-specific temporal and spatial patterns of AMPA receptor exocytosis in hippocampal neurons. Nat Neurosci 4:917-926.

Passafaro M, Nakagawa T, Sala C, Sheng M (2003) Induction of dendritic spines by an extracellular domain of AMPA receptor subunit GluR2. Nature 424:677-681.

Perez-Otano I, Ehlers MD (2004) Learning from NMDA receptor trafficking: clues to the development and maturation of glutamatergic synapses. Neurosignals 13:175-189.

Petralia RS, Wenthold RJ (1992) Light and electron immunocytochemical localization of AMPA-selective glutamate receptors in the rat brain. J Comp Neurol 318:329-354.

Quinlan EM, Olstein DH, Bear MF (1999) Bidirectional, experiencedependent regulation of $\mathrm{N}$-methyl-D-aspartate receptor subunit composition in the rat visual cortex during postnatal development. Proc Natl Acad Sci USA 96:12876-12880.
Quinlan EM, Lebel D, Brosh I, Barkai E (2004) A molecular mechanism for stabilization of learning-induced synaptic modifications. Neuron 41:185-192.

Racca C, Stephenson FA, Streit P, Roberts JD, Somogyi P (2000) NMDA receptor content of synapses in stratum radiatum of the hippocampal CA1 area. J Neurosci 20:2512-2522.

Rensing N, Ouyang Y, Yang XF, Yamada KA, Rothman SM, Wong M (2005) In vivo imaging of dendritic spines during electrographic seizures. Ann Neurol 58:888-898.

Rumpel S, LeDoux J, Zador A, Malinow R (2005) Postsynaptic receptor trafficking underlying a form of associative learning. Science 308:83-88.

Sankaranarayanan SDAD, Rothman JE, Ryan TA (2000) The use of pHluorins for optical measurements of presynaptic activity. Biophys J 79:2199-2208

Sheng M, Kim MJ (2002) Postsynaptic signaling and plasticity mechanisms. Science 298:776-780.

Sheng M, Cummings J, Roldan LA, Jan YN, Jan LY (1994) Changing subunit composition of heteromeric NMDA receptors during development of rat cortex. Nature 368:144-147.

Shi S, Hayashi Y, Esteban JA, Malinow R (2001) Subunit-specific rules governing AMPA receptor trafficking to synapses in hippocampal pyramidal neurons. Cell 105:331-343.

Shi SH, Hayashi Y, Petralia RS, Zaman SH, Wenthold RJ, Svoboda K, Malinow R (1999) Rapid spine delivery and redistribution of AMPA receptors after synaptic NMDA receptor activation. Science 284:1811-1816.

Song I, Huganir RL (2002) Regulation of AMPA receptors during synaptic plasticity. Trends Neurosci 25:578-588.

Sorra KE, Harris KM (1998) Stability in synapse number and size at $2 \mathrm{hr}$ after long-term potentiation in hippocampal area CA1. J Neurosci 18:658-671.

Stoppini L, Buchs PA, Muller D (1991) A simple method for organotypic cultures of nervous tissue. J Neurosci Methods 37:173-182.

Swann JW, Al-Noori S, Jiang M, Lee CL (2000) Spine loss and other dendritic abnormalities in epilepsy. Hippocampus 10:617-625.

Takahashi T, Svoboda K, Malinow R (2003) Experience strengthening transmission by driving AMPA receptors into synapses. Science 299:1585-1588.

Takumi Y, Ramirez-Leon V, Laake P, Rinvik E, Ottersen OP (1999) Different modes of expression of AMPA and NMDA receptors in hippocampal synapses. Nat Neurosci 2:618-624.

Tonegawa S, Nakazawa K, Wilson MA (2003) Genetic neuroscience of mammalian learning and memory. Philos Trans R Soc Lond B Biol Sci 358:787-795.

Toni N, Buchs PA, Nikonenko I, Bron CR, Muller D (1999) LTP promotes formation of multiple spine synapses between a single axon terminal and a dendrite. Nature 402:421-425.

Traub RD, Wong RK (1982) Cellular mechanism of neuronal synchronization in epilepsy. Science 216:745-747.

Wenthold RJ, Petralia RS, Blahos Jr J, Niedzielski AS (1996) Evidence for multiple AMPA receptor complexes in hippocampal CA1/CA2 neurons. J Neurosci 16:1982-1989.

Wollmuth LP, Kuner T, Sakmann B (1998) Adjacent asparagines in the NR2-subunit of the NMDA receptor channel control the voltagedependent block by extracellular $\mathrm{Mg}^{2+}$. J Physiol (Lond) 506:13-32.

Wong M (2005) Modulation of dendritic spines in epilepsy: Cellular mechanisms and functional implications. Epilepsy Behav 7:569-577.

Zador A, Koch C, Brown TH (1990) Biophysical model of a Hebbian synapse. Proc Natl Acad Sci USA 87:6718-6722.

Zamanillo D, Sprengel R, Hvalby O, Jensen V, Burnashev N, Rozov A, Kaiser KM, Koster HJ, Borchardt T, Worley P, Lubke J, Frotscher M, Kelly PH, Sommer B, Andersen P, Seeburg PH, Sakmann B (1999) Importance of AMPA receptors for hippocampal synaptic plasticity but not for spatial learning. Science 284:1805-1811. 